\title{
PERAMALAN PENJUALAN ROTI KENARI ARJUNS BAKERY Di KOTA TERNATE PROVINSI MALUKU UTARA
}

\author{
Hamka*, Ruslan Laisouw** \\ *Staf Pengajar FAPERTA, UMMU-Ternate, e-mail : hamka_agb@yahoo.co.id \\ **Staf Pengajar FMIPA, UMMU-Ternate, $e$-mail : -
}

\begin{abstract}
ABSTRAK
Pada penelitian ini bertujuan untuk mempelajari Pola penjualan roti kenari yang di produksi oleh perusahaan Arjuns Bakery dan mengetahui peramalan roti kenari terbaik dengan menggunakan time serial untuk 3 bualan mendatang. Metode yang digunakan adalah metode time serial dengan menggunakan simple Average, Moving Average dan Simple Eksponensial Smoothing. Hasil penelitian menunjukkan bahawa pola penjualan roti kenari bersifat stasioner atau horisontal, dimana pergerakan data penjualan berada di sekitar rata-rata penjualan roti selama satu tahun sembilan bulan. Nilai peramalan yang diperoleh dengan menggunakan metode time serial adalah Simple Average dengan nilai peramalan 8060 dengan SE 572.84, Moving Average 7713 dengan nilai SE 558.72 yang dianggap baik untuk meramalkan penjualan roti untuk tiga bulan mendatang adalah metode Simple Eksponensial Smoothing dengan nilai peramalan penjualan roti kenari sebesar 7759 buah, dengan nilai SE sebesar 555.03.
\end{abstract}

Kata Kunci: Peramalan, Penjualan, Time Serial

\section{PENDAHULUAN}

\subsection{Latar Belakang}

Pangan merupakan kebutuhan pokok manusia selain papan dan sandang, kebutuhan pangan harus dipenuhi untuk mendukung aktivitas setiap orang, karena pangan mengandung kebutuhan karbohidrat yang merupakan unsur penghasil tenaga yang diproduksi dalam tubuh manusia. Pangan yang seimbang kandungan gizinya akan mempercepat pencapaian tingkat optimal kualitas fisik, mental, intelektual masyarakat sebagai faktor yang berpengaruh terhadap produktivitas kerja (Anonim,2011)

Masyarakat sekarang menyadari bahwa bahan pangan mereka tidak hanya dipenuhi oleh nasi saja, sehingga mereka memilih roti sebagai bahan pangan pengganti. Hal tersebut dikarenakan roti merupakan jenis makanan yang siap untuk dimakan serta mudah penyajiannya, selain itu roti juga tahan lama dibandingkan dengan nasi dan makanan lainnya. Roti tidak hanya dikonsumsi oleh kalangan atas tetapi juga dikonsumsi oleh kalangan menengah dan bawah. Roti merupakan makan yang praktis yang tingkat ketersediaannya mudah diperoleh, mudah penyajiannya, banyak variasi rasa dan bentuk serta kandungan gizi yang baik pula.

Roti semakin penting dan diminati orang banyak akhir-akhir ini, terutama pada masyarakat yang sibuk karena dapat diperoleh dengan lebih mudah dan cepat, baik di pasarpasar swalayan, toko-toko atau warung terdekat, maupun pedagan keliling. Roti merupakan salah satu makanan yang berasal dari pengolahan tepung terigu. Peningkatan konsumsi masyarakat akan makanan olahan tercermin pada konsumsi terigu yang semakin hari semakain meningkat setiap tahunnya.

Arjun'S Bakery adalah salah satu perusahaan roti di Kota Ternate yang memenuhi kebutuhan masyarakat Kota Ternate akan roti sejak tahun 2002, ada beberapa jenis roti yang diproduksi, diantaranya roti kenari, roti keong, roti cokelat, 
roti pandan dan roti manis. Roti kenari, roti keong dan coklat adalah produk unggulan dalam perusahaan tersebut, sehingga perlu penanganan yang khusus untuk menjaga ritme produksi, dalam proses produksinya perusahaan selalu diperhadapkan pada ketidakpastian permintaan akan roti, hal ini mengakibatkan jumlah roti kenari, roti keong dan roti coklat yang diproduksi terkadang habis diserap oleh konsumen dan juga terkadang tidak habis atau sisa.

Selama ini Arjun'S Bakery sering kesulitan dalam merencanakan produksi, mengingat keterbatasan pengetehuan dan informasi. Proses produksi masih mengandalkan pengalaman dan kebiasaan dalam memproduksi roti. Hal inilah yang menyebabkan perusahaan mengalami kesulitan dalam memperkirakan tingkat kebutuhan yang real akan roti di kota Ternate. Oleh karena itu penulis ingin melakukan penelitian tentang peramalan produksi dengan menggumakan metode deret waktu dan kausal, metode ini dirasa sangat tepat mengingat jumlah produksi yang akan diramal hingga tiga bulan kedepan.

Kepastian kebutuhan akan roti, atau minimal mendekati akan kebutuhan permintaan roti di kota Ternate menjadi sangat penting bagi perusahaan, jika hasil prosuksi sering tidak terserap habis dapat menimbulkan kerugian bagi perusahaan. Dengan adanya peramalan yang baik, maka perusahaan dapat dengan mudah memastikan jumlah produksi yag harus di siapkan oleh perusahaan. Jadi untuk mengetahui penjualan yang akan datang, kita harus menggunakan peramalan penjualan. Dengan peramalan penjualan yang baik, perusahaan dapat memperkirakan keuntungan yang akan didapat. Berdasarkan latar belakang dan permasalahan yang di hadapi oleh perusahaan roti Arjun'S Bakery maka peneliti merasa perlu untuk melakukan penelitian besarnya penjualan pada perusahaan Arjun'S Bakey pada bulan yang akan datang.

\subsection{Tujuan Penelitian}

$$
\text { sdsdsadsadadada }
$$

\section{METODE PENELITIAN}

\subsection{Lokasi dan Waktu Penelitian}

Penelitian ini dilaksanakan di Arjun'S Bakery yang berlokasi di lingkungan Kelapa Pendek Kelurahan Mangga dua Utara Kota Ternate .Lokasi penelitian dipilih secara sengaja (purposive). Pertimbangan adalah karena Arjun'S Bakery adalah salah satu perusahaan agribisnis roti yang terdapat di kota Ternate. Penelitian di laksanakan pada bulan Juli - September 2012.

\subsection{Populasi dan Sampel}

Studi kasus pada perusahaan pabrik roti Arjuns Bakery, adapun sumber informasi penjualan diperoleh melalui bagian pemasaran Roti Arjuns Bakery.

\subsection{Teknik Pengumpulan Data}

Data yang akan diolah didapatkan dengan cara pengambilan data secara langsung di perusahaan lewat bagian pemasaran, dimana data yang diambil berupa data penjualan bulan Januari tahun 2011 sampai September 2012.

\subsection{Metode Analisis Data}

Metode yang digunakan untuk peramalan roti Kenari Arjuns Bakery adalah metode peramalan rata-rata sederhana (simple avarage), metode rata-rata bergerak (moving average), metode pemulusan eksponensial (simple exponential smoothing), Untuk meramalkan penjualan roti tiga bulan yang akan datang digunakan metode yang terbaik, yaitu metode yang menghasilkan nilai MSE/SE terkecil.

\subsubsection{Metode Simple Average}

Merupakan metode yang mengambil rata-rata dari seluruh data observasi yang dikumpulkan untuk meramalkan data yang akan datang.

Persamaannya adalah:

$$
X=1 / T\left(X_{1}+X_{2}+X_{3}+\ldots+X t\right)
$$

Dimana:

$X$ = data peramalan yang akan datang

$X_{t}=$ data observasi pada periode ke $t$

$T=$ jumlah periode observasi 


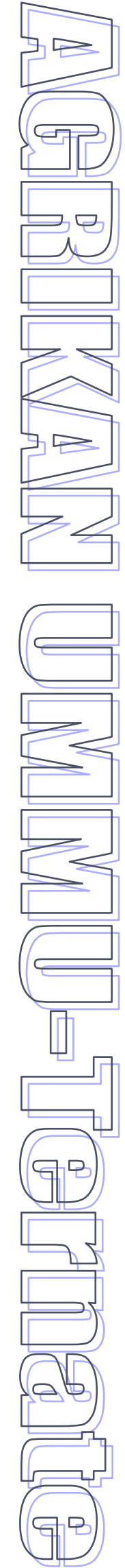

\subsection{Peramalan Roti Arjuns Bakery}

Berdasarkan plot data diketahui bahwa data bersifat stasioner dengan titik penyebaran penjualan berada di sekitar nilai rata-rata data penjualan, maka pendekatan peramalan atau time serial untuk memecahkan peramalan roti pada Arjuns Bakery adalah dengan menggunakan pendekatan yang dikemukakan oleh (Hanke,2005) yakni memakai metode Simple Average, Moving Average dan Simple Eksponesial Smoothing.
Peramalan roti kenari menggunakan 3 metode time serial yakni Simple Average, Moving Average dan Exponensial Smoothing dengan program WinQSB versi 1.0, ketiga motede ini dipilih dengan asumsi memenuhi kriteria penggunaan data penjualan yang dimiliki oleh Arjuns Bakery. Adapun data yang diperoleh dari peramalan Roti Kenari dapat dilihat pada Tabel 1.

Tabel 1. Peramalan Penjualan Roti Kenari Arjuns Bakery menggunakan metode Simple Average, Moving Average dan Exponensial Smoothing untuk peramalan 3 bulan, 2012.

\begin{tabular}{lccc}
\hline \multirow{2}{*}{ Bulan } & \multicolumn{3}{c}{ Metode Time Serial } \\
\cline { 2 - 4 } & Simple Average & Moving Average & $\begin{array}{c}\text { Simple Exponensial } \\
\text { Smoothing }\end{array}$ \\
\hline Oktober & 8060 & 7713 & 7759 \\
November & 8060 & 7713 & 7759 \\
Desember & 8060 & 7713 & 7759 \\
\hline
\end{tabular}

Sumber : Data Primer Setelah diolah, 2012

Berdasarkan data di atas terdapat perbedaan peramalan dari ketiga metode di atas, dimana Metode Simple Average meramalkan untuk 3 bulan mendatang jumlah penjualan roti kenari sebanyak 8060 buah, sementara Metode Moving Average meramalkan penjualan roti kenari untuk 3 bulan mendatang adalah 7713 buah, dan Metode Exponensial Smoothing meramalkan penjaualn roti kenari untuk 3 bualan mendatang adalah sebesar 7759 buah. Dari ketiga metode di atas terlihat bahwa Metode Simple Average meramalkan jumlah penjualan yang lebih banyak dari pada kedua metode lainnya, disusul Metode Moving
Average dan Metode Simple Exponensial Smoothing .

Hasil peramalan di atas belum dapat dijadikan acuan bagi perusahaan dalam menentukan peramalan penjualan yang mana yang harus dipilih, apakah yang paling banyak hasil peramalannya ataukah yang paling sedikit. Pendekatan yang dapat digunakan untuk melihat hasil peramalan yang terbaik, dan dijadikan dasar bagi perusahaan dalam menentukan jumlah penjualan adalah dengan melihat nilai Mean Squared Error (MSE) atau Standar Error (SE) dari tiap-tiap metode peramalan. Adapun hasil MSE atau SE metode peramalan di atas seperti terlihat pada Tabel 2.

Tabel 2. Verifikasi Peramalan Penjualan Roti Kenari Menggunakan Metode, Simple Average, Moving Average dan Exponensial Smoothing untuk Peramalan 3 bulan, Tahun 2012.

\begin{tabular}{lrrr}
\hline & Verifikasi Peramalan & \multicolumn{3}{c}{ Metode Time Serial } \\
\cline { 2 - 4 } & Simple Average & Moving Average & $\begin{array}{c}\text { Simple Exponensial } \\
\text { Smoothing }\end{array}$ \\
\hline MSE & 327001 & 312173 & 308058 \\
SE & 572.84 & 558.72 & 555.03 \\
\hline
\end{tabular}

Sumber : Data Primer Setelah diolah,2012

Berdasarkan hasil verifikasi model peramalan diperoleh bahwa nilai MSE terkecil adalah 308058. Jika menggunakan pendekatan SE terkecil maka diperoleh SE terkecil adalah 555.02 dengan metode peramalan penjualan roti kenari Arjuns Bakery yang tepat dan bisa digunakan oleh perusahaan untuk meramalkan penjualan roti untuk 3 bulan mendatang adalah metode Simple Exponensial Smoothing dengan nilai peramalan roti kenari untuk 3 bualan mendatang sebesar 7759 . 
3.3. Rekomendasi Kebijakan Penjualan

Berdasarkan hasil peramalan yang dilakukan dengan menggunakan pendekatan metode Simple Average, Moving Average dan Simple Exponensial Smoothing, maka rekomendasi yang bisa diajukan bagi perusahaan adalah Plot data penjualan bersifat stasioner, hal ini berarti Roti Kenari memiliki peluang untuk meningkat, agar perusahaan dapat meningkatkan omset penjualannya maka langkah yang dapat ditempuh adalah dengan melakukan perluasan penjualan lewat penambahan outlet-outlet penjualan Roti Kenari Arjuns Bakery.

Hasil peramalan menunjukkan kenaikan roti pada 3 bualan mendatang masih berada di atas rata-rata penjualan roti, hal ini berarti perusahaan harus lebih memperluas jaringan outlet atau kios yang selama ini berfungsi sebagai tempat dimana roti-roti Arjuns Bakery dipasarkan.

\section{PENUTUP}

Berdasarkan hasil penelitian yang telah dilakukan maka dengan ini dapat disimpulkan bahwa :

1. Pola penjualan roti yang dimiliki oleh Pabrik Roti Arjun Bakery bersifat Stasioner. Hal ini diperlihatkan dengan pergerakan data penjualan yang berada di antara ratarata penjualan roti yang dilakukan oleh Pabrik Roti Arjuns Bakery.

2. Metode peramalan roti yang terbaik untuk Roti Kenari adalah metode Simple Exponensial Smoothing dengan besar ramalan untuk 3 bulan mendatang adalah 7759 buah.

\section{DAFTAR PUSTAKA}

Arsyad, L. 1995 Peramalan Bisnis. Badan Penerbit Fakultas Ekonomi, Yogyakarta. Hanke,John,W. Wichern Dean. Business Forecasting. 2005. Pearson Education,Inc Kosasih Sobarsa, 2009. Manajemen Operasional. Mitra Wacana Media, Jakarta

Makridakis, S., S.C. Wheelwright dan R.J. Hyndman, 1998, Forecasting Methods and Applications, 3 ed, John Wiley \& Sons, New York

Mulyono, S. 2000. Peramalan Bisnis dan Ekonometrika. Edisis ke-1 Badan Penerbit Fakultas Ekonomi Yogyakarta

Pangestu Subagyo. 1986. Forcasting Konsep dan Aplikasi. Badan Penerbit Fakultas Ekonomi, Yogyakarta

Rabbab, 2002. Analisis Pengendalian Persediaan Bahan Baku Produk Roti di Cenral Family Bakery Cinere, Jakarta. Skripsi.Jurusan ilmu-ilmu Sosial Ekonomi Pertanian. Fakultas Pertanian, Institut Pertanian Bogor.

Sugiarto dan Harijono, 2002. Peramalan Bisnis. PT Gramedia Pustaka Utama, Jakarta

US Wheat Associates, 1983. Pedoman Pembuatan Roti dan Kue.Djambatan, Jakarta. 